logos_i_ethos_2016_(40)_numer_specjalny_1, s. 155-161

DOI: http://dx.doi.org/10.15633/lie.1705

Wojciech Bartłomiej Zieliński

Uniwersytet Papieski Jana Pawła II w Krakowie

\title{
Przyjemność jako źródło wspólnoty
}

Gdy snuje się rozważania na temat przyjemnego życia społecznego, na myśl przychodzą fantazje utopijne, które stają się zbiorami marzeń dotyczących „doskonałych” mechanizmów funkcjonowania zbiorowości ludzkiej. Tym samym mimowol-

Wojciech Bartłomiej Zieliński, mgr filozofii, student Akademii Sztuk Pięknych im. Jana Matejki w Krakowie, doktorant na Uniwersytecie Papieskim Jana Pawła II. Zainteresowania naukowe: socjologia wiedzy, fenomenologia świata politycznego, filozofia społeczna, filozofia języka, językoznawstwo. nie plasują się na pozycji maksimum na skali oceniania stanu obecnego, jeszcze dobitniej ukazując jego niedoskonałości. W ramach poniższego szkicu przyjemność będzie rozważana nie jako element dążności zawarty w przedstawieniach futurologicznych, lecz jako warunek sine qua non istnienia wspólnoty. Jednostka będąca członkiem grupy ma wobec niej roszczenia, a jednym z podstawowych jest właśnie odczuwanie zadowolenia z przynależności.

\section{„Miałem sen”}

Pojęciem kluczowym dla podejmowanych rozważań jest wyobraźnia, a właściwie definicja i jej konsekwencje wyprowadzone przez Immanuela Kanta. Odwołując się do koncepcji tego filozofa, należy stwierdzić, że mamy do czynienia $\mathrm{z}$ bardzo specyficzną sferą działalnością ludzkiego rozumu, opartą o „wyjątkowe obrazy”. Ich niezwykłość polega na tym, że co prawda powstają na podstawie danych empirycznych, lecz bodźce nie łączą się na logicznych zasadach intelektu. Wówczas mielibyśmy do czynienia z wiedzą, a co za tym idzie - z jej kryterium, jakim jest prawda. Wspomniane wyobrażenia nie mają roszczeń egzystencjalnych, 
a jedynie dążą do maksymalizacji uczucia przyjemności ${ }^{1}$. Przykładem dla tego typu wytworów ludzkiego umysłu jest pegaz - koń ze skrzydłami. Każdy z nas dobrze wie, jak wyglądają koń oraz skrzydła, wedle definicji podanej w encyklopedii księdza Benedykta Chmielowskiego: „Koń, jaki jest, każdy widzi”. Sytuacja ta wynika właśnie z wiedzy, tj. logicznego połączenia danych zmysłowych. Natomiast wizja latającego nieparzystokopytnego ssaka jest złączeniem dwóch różnych obrazów, $\mathrm{w}$ żaden sposób niewystępujących $\mathrm{w}$ takiej formie $\mathrm{w}$ przyrodzie; podobnie jest np. z różowymi słoniami, jednorożcami, syrenami itp. Zatem wyobraźnia nie jest tworzeniem ex nihilo, tylko - posługując się nomenklaturą myśliciela $\mathrm{z}$ Królewca - nielogicznym komponowaniem bodźców w celu stania się wyznacznikiem dla odczuwania przyjemności lub przykrości. Wszak wszelakie fantazyjne stwory, czy to opisywane w literaturze, czy przedstawiane na ilustracjach, odwołują się nie do wiedzy, lecz wyobraźni i jej wytworów. Oczywiście zagadnienie to nie ogranicza się do humanoidalnych galaktycznych wojowników, latających świń itp., ale do całości pozalogicznych wyobrażeń (w tym oczywiście całej sfery sztuki i muzyki).

Wstępnie należy odróżnić opisywane tutaj odczuwanie od partycypowania w pięknie, które to zalicza się do sfery wiedzy; jest ogromna różnica sądem, że dany przedmiot jest piękny - bo odwołujemy się wówczas do obiektywnych właściwości przedmiotu, np. harmonii dźwięków lub podziałów geometrycznych - a stwierdzeniem, że coś mi się podoba.

Okazuje się więc, że tak opisana wyobraźnia, a co za tym idzie - zdolność oceniania czegoś jako przyjemnego czy przykrego, jest narzędziem indywidualnego podmiotu. Co więcej, Kant stwierdza, że nie można nikomu narzucić swojego upodobania, choć każda jednostka ma ku temu skłonności; przecież każdy chłopak chce, aby jego dziewczynę uznać za najładniejszą w ogóle, jednak, jak się okazuje, nawet argumenty siłowe nie są wstanie być gwarantem osiągnięcia sukcesu w kwestii grupowego odczucia przyjemności wobec jednego przedmiotu. Jak zatem można na

1 Por. I. Kant, Krytyka władzy sądzenia, tłum. J. Gałecki, Warszawa 1964, s. 43, 48, 81, 86, 104, 110; J. Szczepański, Polityczna władza sądzenia, Kraków 2009, s. 77. 
kanwie tej propozycji mówić o kamieniu węgielnym istnienia wspólnoty, skoro konstrukcja oparta o propozycję królewieckiego myśliciela doprowadza raczej do atomizacji i indywiduacji? Z propozycją rozwiązania tego problemu przychodzi koncepcja dialektyki Marksa. Zanim jednak przejdziemy do kolejnego etapu analiz, zwróćmy uwagę na najbardziej istotny z naszego punktu widzenia element Krytyki władzy sądzenia: wyobraźnia i jej twory nie mają charakteru wiedzy, a luźny stosunek do rzeczywistości pozwala na ocenę świata wedle klucza wyznaczonego przez kategorię przyjemności. Takie ujęcie da możliwość lepszej analizy marksowskiej ideologii, która przybliża do próby odpowiedzi na zadany temat.

\section{Ideologia}

Autor Kapitału, będąc obok Zygmunta Freuda i Fryderyka Nietzschego jednym z mistrzów podejrzeń, zastanawia się nad tym, skąd bierze się błędny osąd rzeczywistości, który według jego koncepcji ma się objawiać tym, że nie zmienia bytu materialnego, a jest jedynie spekulacją na jego temat (co wyraża w swej koncepcji wartości wymiennej). Co ciekawe, niemożność zmiany materii zależna jest od stosunku podmiotu do niej samej. Owa relacja ujęta jest jako ideologia, tj. relacje ekonomiczne wpływają na obraz świata dostępny danej klasie społecznej - byt określa świadomość. Ta jest $\mathrm{z}$ kolei niczym innym jak zestawem pewnych roszczeń opartym na wyobrażeniu wynikającym właśnie z ekonomicznego odniesienia do świata. Już teraz zauważamy istotną cechę struktury - hipotetyczność, brak praktycznego, tj. zdolnego do przekształcenia bytu, działania. Dodatkowo, czego nie było w koncepcji kantowskiej, mamy tu do czynienia z czymś ponadindywidualnym, pośrednio fundującym wspólnotę (przede wszystkim opartą o stosunki produkcji). Można więc sugerować, że ideologia nie tłumaczy świata, a jedynie wytwarza pewien balon spekulacji, którego zadaniem jest zaspokojenie wyobrażeń o świecie ${ }^{2}$. Oczywiście,

2 Por. A. Schaff, Ideologia w ujęciu Mannheima, Warszawa 1958, s. 7; K. Marks, F. Engels, Dzieła, t. 23, Warszawa 1968, s. 18. 
mamy do czynienia z pewnego rodzaju tłumaczeniem faktów, ale jest ono dokonywane ze względu określony pogląd, a nie jako jego weryfikacja. Zatem teoretyczna konstrukcja opisana przez Marksa ma za zadanie spełnienie wyobrażenia, czyli - ujmując to terminologią Kanta - ma dać przyjemność. Natomiast podstawą do wysunięcia tezy o ponadindywidualnym wyobrażeniu jest wspólny interes (podobny status ekonomiczny).

\section{Dlaczego nie o szczęściu?}

Powróćmy do zasygnalizowanego wcześniej problemu z kategorią piękna, który wprowadza w szerszy kontekst oparty na pytaniu: dlaczego analizujemy przyjemność i dlaczego żadna kategoria aksjologiczna nie jest analizowana jako fundament społeczeństwa? Odpowiedź bazować będzie na systemach Platona i Arystotelesa, w których szczęście jest efektem życia cnotliwego - działania jednostkowego ze względu na dobro czy piękno. Zatem mamy do czynienia z elementami ogólnodostępnymi (obiektywnymi), w osiąganiu których struktury państwowe nie są niezbędne, choć, jak sugerują zarówno starożytni, jak i Kant czy Hegel, są pomocne poprzez ustanawianie odpowiednich praw. Tym samym nie daje to możliwości rozważenia tego zagadnienia jako konstruktywnego dla istnienia wspólnoty.

Metafizyczny kontekst sprawia, że mamy do czynienia z jednostkowym autodoskonaleniem bytu człowieka (należy pamiętać, że indywidualizm nie oznacza egoizmu). Natomiast, gdy odrzucimy kategorie prawdy, piękna czy też dobra i skupimy się, jak sugeruje to Marks, na ideologii, czyli zbiorowym wyobrażeniu - złudzeniu - otrzymujemy możliwość mówienia o grupach ludzi. Taki stan rzeczy doprowadza do wniosku, że to nie wspólna wiedza czy też ponadindywidualny intelekt ani wzrastanie $\mathrm{w}$ cnotach jest przedmiotem naszych poszukiwań. Ten znajduje się raczej po drugiej stronie barykady i jawi się jako zbiorowa fantazja, mit przykładany niczym szablon do otaczającego świata. 


\section{Władcy umysłów}

Zagadnienie zbiorowego wyobrażenia skłania do namysłu nad możliwością i mechanizmami jego kreacji. Marks, jak zostało już wspomniane, uzależniał je od przynależności do klasy, czyli de facto statusu ekonomicznego. By rozwinąć kwestię wytwórstwa obrazu, odwołajmy się do myśli obecnej w drugiej połowie wieku XX. Można stwierdzić, że wyobrażenie grupowe jest niczym innym jak potrzebą społeczną - dlatego rozważać tę kwestię należy między innymi w kontekście konsumpcjonizmu, zaspokajania pragnień oraz pragmatyzmu.

Kontynuując koncept marksowski, należy stwierdzić, że siły wpływające na wyobraźnię nie działają wprost. Na co wskazuje również Zygmunt Bauman, działanie bezpośrednie przy pomocy aparatu nakazów i zakazów jest w swym wyrazie opresyjne $e^{3}$. Myśliciel ten sugeruje działania „podskórne”, wypowiedź ta podobna jest do teorii Michela Foucaulta. W koncepcji drugiego filozofa wyróżnione zostają trzy formy stosunków władczych: dominacja rozumiana jako ucisk, rządzenie ujęte w ramy zinstytucjonalizowanego postępowania oraz władza instytucjonalna i pozaformalna (kapilarna, czyli totalna). Silna władza zostaje przedstawiona jako oparta na autorytecie egzemplifikowanym przez bóstwo lub mit. Ostoją władzy jest zwyczaj, rytuał i wyrażająca obydwa opinia publiczna ${ }^{4}$. Całość daje się wpisać w ramy, które nakreślił Marks, pisząc o stosunkach ekonomicznych jako podstawie dla podziałów społeczno-politycznych. W ten sposób obnażone zostają siły działające poza prawem stanowionym, wyrażające władzę. Oznacza to również, że podawany w ten sposób obraz, wyobrażenie na temat rzeczywistości, przyjmujemy jako własny, bezsprzeczny i oczywisty. Można dodać do tej konstrukcji „estetyzację"5, a właściwie uprzyjemnienie przestrzeni publicznej, czyli wyjście naprze-

3 Por. Z. Bauman, Praca, konsumpcjonizm i nowi ubodzy, tłum. S. Obirek, Kraków 2006, s. 59 nn.

4 Por. M. Żardecka-Nowak, Władza kształtująca jednostkę, [w:] Wolność $i$ władza w życiu publicznym, red. W. Zuziak, J. Mysona Byrska, Kraków 2008, s. 104n.

Cudzysłów ma uświadomić, że nie chodzi tutaj o estetyzację de facto, ponieważ poruszamy się poza metafizycznymi pojęciami piękna i brzydoty. 
ciw oczekiwaniom, które są kreowane w systemie - podmiot jest w ciągłej gotowości ${ }^{6}$ do zaspokojenia i dąży ku niemu.

Sytuację, w której podmiot ciągle dąży do zaspokojenia społecznego wyobrażenia i używa do tego różnorakich, odpowiednio zinterpretowanych przejawów rzeczywistości, przedstawia Karl Mannheim. Gdy opisuje on zjawisko noologiczne, którym wedle niego jest ideologia, odwołuje się do przykładu chrześcijańskiej miłości bliźniego ${ }^{7}$. Jest to wizja niewynikająca ani z wiedzy o świecie, ani z prawa stanowionego. Natomiast zaspokajana poprzez złożenie różnych elementów tak, jak przedstawiał to Kant, w efekcie czego jednostka odczuwa przyjemność niepokrywającą się z kategorią prawdy czy nawet piękna.

\section{Wątpliwości}

Istotną kwestią zdaje się to, czy społeczne konstrukcje nie działają na zasadzie samozadowolenia - wytworzenia wyobrażenia i jednoczesnego zaspokojenia. Wydaje się, że taki stan miał na myśli Nietzsche, pisząc o dekadencji i ostatnim człowieku: „Ziemia się skurczyła, a po niej skacze ostatni człowiek, który wszystko zdrabnia. [...] «Myśmy szczęście wynaleźli» - mówią ostatni ludzie i mrużą niedbale oczy. [...] Cierpienie i nieufność uchodzą za rzeczy grzeszne; ostatni człowiek baczy troskliwie na siebie. Głupiec chyba tylko potyka się jeszcze o kamienie i o ludzi! Nieco trucizny kiedy niekiedy: to darzy słodkimi snami. A w końcu - dużo trucizny, aby mile zemrzeć. Pracuje się jeszcze, gdyż praca jest rozrywką. Dba się jednak o to, by ta rozrywka nie stała się zbyt uciążliwą. [...] Sprzeczają się jeszcze, lecz godzą się niebawem, gdyż niezgoda psuje żołądek. Ma się swą przyjemnostkę na dzień i swą przyjemnostkę na czas nocy; lecz zdrowie ceni się nade wszystko. «Myśmy szczęście wynaleźli» - mówią ostatni ludzie i mrużą oczy"s.

6 Por. Z. Bauman, Praca, konsumpcjonizm i nowi ubodzy, dz. cyt., s. 69, 67.

7 Por. K. Mannheim, Ideologia i utopia, tłum. J. Miziński, Warszawa 2008, s. 232.

8 F. Nietzsche, Tako rzecze Zaratustra. Książka dla wszystkich i dla nikogo, tłum. W. Berent, Poznań 1995, s. 14. 
Doprowadza to do pytania, czy rzeczywiście w pełni usatysfakcjonowane społeczeństwo jest stanem właściwym. Czy w efekcie realizacja utopii - społeczna sytość - sprawi, że nie będzie możliwości rozwoju, a takiej grupie - jak sugeruje Emil Cioran ${ }^{9}$ - będzie groziła skleroza i beznadzieja? Wydaje się, że w krainie mlekiem i miodem płynącej potrzebna jest łyżka dziegciu. Co wcale nie ujmuje samej propozycji ukazania wyobraźni i zaspakajania jej wytworów jako fundamentu społeczeństwa.

\section{Zakończenie}

Poruszona w tekście kwestia jest ciekawą propozycją w kontekście poszukiwań źródeł wspólnoty. Okazuje się, że zarówno zaspokojenie pragnienia przyjemności, jak i wytworzenie wyobrażenia (w procesie socjalizacji) leży w gestii społeczeństwa. Tym samym można wysnuć wniosek, że każdy pegaz, każde miasto słońca zawiera implicite żądanie spełnienia.

\section{Bibliografia}

Bauman Z., Praca, konsumpcjonizm i nowi ubodzy, tłum. S. Orbitek, Kraków 2006.

Kant I., Krytyka władzy sądzenia, tłum. J. Gałecki, Warszawa 1964.

Mannheim K., Ideologia i utopia, tłum. J. Miziński, Warszawa 2008.

Marks K., Engels F., Dzieła, t. 23, Warszawa 1968.

Nietzsche F., Tako rzecze Zaratustra. Książka dla wszystkich i dla nikogo, tłum. W. Berent, Poznań 1995.

Schaff A., Ideologia w ujęciu Mannheima, Warszawa 1958.

Szacki J., Spotkania z utopia, Warszawa 2000.

Szczepański J., Polityczna władza sądzenia, Kraków 2009.

Żardecka-Nowak M., Władza ksztattująca jednostkę, [w:] Wolność i władza w życiu publicznym, red. W. Zuziak, J. Mysona Byrska, Kraków 2008, s. 103-120.

9 E. Cioran, Historia i utopia, tłum. M. Bieńczyk, Warszawa 1997, s. 66, cyt. za: J. Szacki, Spotkania z utopia, Warszawa 2000, s. 5. 